\title{
FAKTOR YANG MEMPENGARUHI NYERI PADA PASIEN FRAKTUR DI RSUD SALEWANGAN MAROS
}

\author{
Junaiddin \\ Sekolah Tinggi IImu Kesehatan (STIKES) Papua \\ Alamat korespondensi : (Junaiddin92@gmail.com/085215509246)
}

\begin{abstract}
ABSTRAK
Fraktur merupakan terputusnya kontinuitas jaringan tulang, retak atau patahnya tulang yang utuh, yang biasanya disebabkan oleh trauma / ruda paksa atau tenaga fisik yang ditentukan jenis dan luasnya trauma. nyeri sebagai suatu sensori subjektif dan pengalam emosinal yang tidak menyenangkan berkaitan dengan kerusakan jaringan yang aktual, potensial, atau yang dirasakan dengan kejadian - kejadian saat terjadi kerusakan. Teknik relaksasi nafas dalam dan teknik distraksi di percaya dapat menurunkan nyeri dengan merelaksasikan ketegangan otot yang mendukung rasa nyeri. Tujuan penelitian ini untuk mengetahui pengaruh dukungan keluarga terhadap penurunan nyeri pada pasien fraktur di RSUD Salewangan Maros. Penelitian ini menggunakan jemis penelitian quasi-eksperimental dengan rancangan one group pre test and post test design. Pengambilan sampel dengan menggunakan teknik accidental sampling.. Pengumpulan data dilakukan dengan menggunakan lembar observasi dan dianalisis dengan uji Wilcoxon $(p<0,05)$ untuk menguji menguji antara dua pengamatan pada situasi sebelum dan sesudah proses untuk menjawab hipotesis data yang kita miliki. Hasil bivariat menunjukkan adanya pengaruh antara dukungan keluarga terhadap penurunan nyeri pada pasien fraktur $(p=0,000)$. Kesimpulan dalam penelitian ini adalah dukungan keluarga merupakan faktor yang paling dominan mempengaruhi penurunan nyeri fraktur.
\end{abstract}

\section{Kata Kunci : Penurunan Nyeri Fraktur, Dukungan Keluarga}

\section{PENDAHULUAN}

Nyeri merupakan bentuk ketidaknyamanan, yang didefinisikan dalam berbagi perspektif. Asosiasi internasional untuk penelitian nyeri (International Association The Study of Pain, 1979) sebagaimana dikutip dalam Susanne C. Smeltzer (2002 ), mendefinisikan nyeri sebagai suatu sensori subjektif dan pengalam emosinal yang tidak menyenangkan berkaitan dengan kerusakan jaringan yang aktual, potensial, atau yang dirasakan dengan kejadian - kejadian saat terjadi kerusakan (Andarmoyo S. 2013. Hal : 16 ).

Badan Kesehatan dunia ( WHO ) mencatat tahun 2007 terdapat lebih dari delapan juta orang meninggal dikarenakan insiden kecelakaan dan sekitar 2 juta orang mengalami kecacatan fisik. Salah satu insiden kecelakaan yang memiliki angka kejadian yang cukup tinggi yakni insiden fraktur ekstremitas bawah yakni sekiatr 46,2 dari insiden kecelakaan yang terjadi (TRiono, Puji. 2015. Hal : 1116)

Di indonesia terjadi kasus fraktur yang disebabkan oleh cedera antara lain karena jatuh, kecelakaan lalu lintas dan trauma benda tajam / tumpul. Dari 45.987 peristiwa tejatuh yang mengalami fraktur sebanyak 1.775 orang $(3,8 \%)$, dari 20.829 kasus kecelakaan lalu lintas, yang mengalami fraktur 1.770 orang $(8,5 \%)$, dari 14.127 trauma benda tajam / tumpul, yang mengalami fraktur sebnayak 236 orang $(1,7 \%)$ (Depkes, RI. 2011).

Provinsi Sulawesi Selatan merupakan provinsi dengan angka kecelakaan yang tinggi. Menurut Riskedes 2013 dalam Ariesanti Mia ( 2015 ), Prevalansi cedera tertinggi secara nasional adalah di Sulawesi Selatan yaitu sebesar $12,8 \%$. Selain itu, prevalansi cedera akibat transportasi darat mengalami peningkatan dari $25,9 \%$ menjadi $47,7 \%$.

Berdasarkan data yang diperoleh dari rekam medik RSUD Salewangan Maros, prevalensi kasus fraktur terus meningkat dari tahun ketahun. Dari tahun 2012 terdapat 120 pasien fraktur, tahun 2013 sebanyak 136 pasien, tahun 2014 sebanyak 180 pasien dan pada tahun 2015 sebanayak 206 pasien fraktur (Rekam Medik RSUD SalewanganMaros, 2016).

Berdasarkan uraian dan permasalahan tersebut penulis tertarik untuk melakukan penelitian tentang "Faktor yang Mempengaruhi Penurunan Nyeri pada Pasien Fraktur di RSUD Salewangan Maros “

\section{BAHAN DAN METODE}

Lokasi, Populasi dan Sampel

Penelitian pra-eksperimental adalah suatu prosedur penelitian dengan memberikan perlakuan pada subjek penelitian dengan tujuan untuk menilai pengaruh suatu perlakuan 
sebagai variabel bebas terhadap variabel terikat dengan rancangan tertentu. Telah dilaksanakan di RSUD Salewangan Maros pada tanggal 2 Desember 2016 sampai dengan 2 Januari 2017. Populasi dalam penelitian ini adalah semua pasien Fraktur di RSUD Salewangan pada bulan oktober 2016 adalah sebanyak 27 pasien dengan jumlah sampel pada penelitian ini adalah 24 orang:

1. Kriteria inklusi dalam penelitian adalah :
a. Pasien Post operasi fraktur di ruang rawat inap RSUD Salewangan Maros
b. Bersedia menjadi responden

2. Kriteria eksklusi
a. Pasien fraktur yang mengalami penurunan kesadaran saat dilakukan penelitian
b. Pasien fraktur dengan skala nyeri sangat berat.
c. Pasien fraktur yang tidak bersedia menjadi responden.

\section{Pengumpulan Data}

1. Editing (mengedit)

Editing merupakan kegiatan untuk pengecekan dan perbaikan isian formulir atau kusioner

2. Coding (pengkodean)

Mengubah data berbentuk kalimat atau huruf menjadi data angka atau bilangan.

3. Tabulation ( Tabulasi )

Setelah melakukan pengelompokan data tersebut dimasukkan kedalam table tertentu sifat-sifat yang dimiliki sesuai dengan tujuan penelitian.

Analisa Data

1. Analisis Univariat

Analisa data ini dilakukan terhadap tiap variable dari penelitian dan pada umumnya dalam analisis ini hanya menghasilkan distribusi dan persentase dari setiap variable.

2. Analisis Bivariat

Analisa Bivariat adalah analisa yang dilakukan terhadap dua variable yang diduga ada hubungan atau korelasi dengan menggunakan uji statistic Wilcoxon (Paired T-Test).

\section{HASIL PENELITIAN}

1. Analisis Univariat

Tabel 1 distribusi frekuensi berdasarkan umur responden. $(n=24)$

\begin{tabular}{|c|c|c|}
\hline Karakteristik & $\mathrm{n}$ & $\%$ \\
\hline Umur & & \\
$16-25$ & 6 & 25 \\
$26-35$ & 8 & 33 \\
$36-45$ & 3 & 13 \\
$45-55$ & 7 & 29 \\
\hline
\end{tabular}

\begin{tabular}{|c|c|c|}
\hline $\begin{array}{c}\text { Jenis Kelamin } \\
\text { Laki-laki } \\
\text { Perempuan }\end{array}$ & $\begin{array}{l}13 \\
11\end{array}$ & $\begin{array}{l}54 \\
46\end{array}$ \\
\hline $\begin{array}{c}\text { SD } \\
\text { SMP } \\
\text { SMA } \\
\text { DIPLOMA }\end{array}$ & $\begin{array}{c}3 \\
7 \\
11 \\
3\end{array}$ & $\begin{array}{l}12,5 \\
29,2 \\
45,8 \\
12,5\end{array}$ \\
\hline $\begin{array}{l}\text { Pekerjaan } \\
\text { PNS } \\
\text { Swasta } \\
\text { Petani } \\
\text { Mahasiswa } \\
\text { IRT } \\
\text { DLL }\end{array}$ & $\begin{array}{l}3 \\
5 \\
4 \\
6 \\
3 \\
3\end{array}$ & $\begin{array}{c}12,5 \\
20,8 \\
16,7 \\
25 \\
12,5 \\
12,5\end{array}$ \\
\hline $\begin{array}{c}\text { Jenis Fraktur } \\
\text { Femur } \\
\text { Tibia } \\
\text { Humerus } \\
\text { Ulna }\end{array}$ & $\begin{array}{l}8 \\
7 \\
5 \\
4\end{array}$ & $\begin{array}{l}33,3 \\
29,2 \\
20,8 \\
16,7\end{array}$ \\
\hline $\begin{array}{c}\text { Variabel } \\
\text { Nyeri Ringan } \\
\text { Nyeri Sedang } \\
\text { Nyeri Berat }\end{array}$ & $\begin{array}{c}3 \\
16 \\
5\end{array}$ & $\begin{array}{l}12,5 \\
66.7 \\
20,8 \\
\end{array}$ \\
\hline $\begin{array}{l}\text { Variabel } \\
\text { Nyeri Ringan } \\
\text { Nyeri Sedang } \\
\text { Nyeri Berat }\end{array}$ & $\begin{array}{l}9 \\
0\end{array}$ & $\begin{array}{c}37,5 \\
0\end{array}$ \\
\hline $\begin{array}{c}\text { Dukungan Keluarga } \\
\text { Dilakukan } \\
\text { Tidak Dilakukan }\end{array}$ & $\begin{array}{c}20 \\
4 \\
\end{array}$ & $\begin{array}{l}83,3 \\
16,7\end{array}$ \\
\hline
\end{tabular}

Pada table 1 menunjukkan dari 24 Responden umur terbanyak adalah pasien fraktur yang berumur 26-35 tahun yaitu sebanyak 8 orang $(33 \%)$, kemudian yang berumur $45-55$ tahun yakni 7 orang $(29 \%)$, dan 16-25 tahun yakni 6 responden (25\%), terakhir yaitu pasien fraktur yang berumur 36-45 tahun (13\%). Berdasarkan jenis kelamin responden terbanyak adalah pasien yang berjenis kelamin laki - laki sebanyak 13 orang dengan persentase $54 \%$ dan paien bejenis kelamin perempuan sebanyak 11 orang dengan persentase $46 \%$. Berdasarkan pendidikan responden terbanyak adalah pasien yang berpendidikan SMA sebanyak 11 orang dengan persentase $45,8 \%$, dan yang terendah adalah pasien yang berpendidikan SD dan Diploma sebanyak 3 orang dengan persentase 12,5\%. Berdasarkan pekerjaan responden terbanyak adalah pasien dengan jenis pekerjaan sebagai mahasiswa sebanyak 6 orang dengan persentase $25 \%$,sedangkan yang terendah adalah pasien dengan jenis pekerjaan sebagai pegawai, IRT, Tidak bekerja sebanyak 3 orang dengan persentase $12,5 \%$. Berdasarkan Lokasi 
fraktur sebagian besar responden mengalami fraktur femur sebanyak 8 orang $(33,3 \%)$, fraktur Tibia sebanyak 7 orang $(29,2 \%)$, dan fraktur humerus 5 orang $(20,8 \%)$, Ulna sebanyak 4 orang $(16,7 \%)$.

2. Analisis Bivariat

Tabel 2 distribusi frekuensi tabulasi silang antara dukungan keluarga dan skal nyeri

\begin{tabular}{|c|c|c|c|c|c|c|}
\hline \multirow{3}{*}{$\begin{array}{c}\text { Penurunan } \\
\text { Nyeri } \\
\text { Fraktur }\end{array}$} & \multicolumn{4}{|c|}{ Dukungan keluarga } & \multirow{2}{*}{\multicolumn{2}{|c|}{ Total }} \\
\hline & \multicolumn{2}{|c|}{ Dilakukan } & \multicolumn{2}{|c|}{$\begin{array}{c}\text { Tidak } \\
\text { Dilakukan }\end{array}$} & & \\
\hline & $\mathrm{n}$ & $\%$ & $\mathrm{n}$ & $\%$ & $\mathrm{n}$ & $\%$ \\
\hline $\begin{array}{c}\text { Ada } \\
\text { Penurunan }\end{array}$ & 13 & 54,2 & 2 & 8,3 & 15 & 62,5 \\
\hline $\begin{array}{l}\text { Tidak Ada } \\
\text { Penurunan }\end{array}$ & 7 & 29,2 & 2 & 8,3 & 9 & 37,5 \\
\hline Total & 20 & 83,4 & 4 & 16,6 & 24 & 100 \\
\hline & & $P=$ & 0,00 & & & \\
\hline
\end{tabular}

Dari tabel 2 menunjukkan bahwa 20 responden $(83,3 \%)$ yang melakukan dukungan keluarga, 13 orang diantaranya $(54,2 \%)$ mengalami penurunan nyeri dan 7 orang $(29,2)$ tidak mengalami penurunan nyeri Dari hasil uji statisti dengan Wilcoxon menunjukkan bahwa nilai Asymp Sig yaitu $0,000(p<0,05)$ dengan demikian Ho ditolak dan Ha di terima artinya ada pengaruh dukungan keluarga terhadap penurunan nyeri pada pasien fraktur di RSUD Salewangan Maros.

\section{PEMBAHASAN}

Pengaruh dukungan keluarga terhadap penurunan nyeri pada psien fraktur di RSUD Salewangan Maros. Hasil penelitian dari 20 responden berdasarkan pemberian dukungan keluarga, ada penurunan nyeri sebanyak orang 13 orang 65\%), dan responden yang tidak mengalami penurunan nyeri sebanyak 7 orang (35\%).

Berdasarkan hasil uji Wilcoxon dapat diketahui bahwa variabel teknik nafas dalam diperoleh nilai $p=0,000(p<\alpha)$, Ha diterima. Hal ini berarti ada pengaruh dukungan keluarga terhadap penurunan nyeri pada pasien fraktur di RSUD Salewangan Maros.

Penelitian ini didukung oleh penelitian sebelumnya yang dilakukan oleh Chandra Bagus (2012) dalam penelitiannya tentang "Analisis Faktor yang Berhubungan dengan Status Fungsional Pasien Paska Open Reduction Internal Fixation (ORIF)" yang menyatakan bahwa dukungan keluarga yang merupakan dukungan sosial dapat digunakan sebagai motivasi untuk menigkatkan kesehatan, mengurangi kecemasan dan mempengaruhi status fungsional pasien Paska Open Reduction Internal Fixation (ORIF).
Dukungan keluarga adalah sikap, tindakan, dan penerimaan keluarga terhadap pasien yang sakit, krluarga berfungsi sebagai system pndukung bagi anggota keluarganya, diamana angota keluarganya memandang bahwa orang yang bersifat mendukung, selalu siap memberikan pertolongan dan banutan jika diperlukan.

Faktor yang bermakna yang mempengaruhi respon nyeri ialah kehadiran orang - orang terdekat klien dan bagaimana sikap mereka terhadap klien. Individu yang mengalami nyeri seringkali bergantung pada anggota keluarga atau teman dekat untuk memperoleh dukungan, bantuan, atau perlindungan. Walaupun nyeri tetap klien rasakan, kehadiran orang dicintai klien akan meminimalkan kesepian dan ketakutan. Apabila tidak ada keluarga atau teman, seringkali pengalam neyri membuat klien semakin tertekan. Kehadiran orang tua sangat penting bagi anak - anak yang sedang mengalami nyeri (Andarmoyo, S. 2013. Hal : 75).

Dukungan keluarga diberikan untuk mengurangi perasaan sedih, nyeri, lemah, tidak berdaya, yang pada umumnya dialami pasien fraktur. Pemberian dukungan baik moril maupun materil dapat menumbuhkan, meningkatkan harga diri, rasa percaya diri pasien dalam menghadapi pemyakitnya. Dukungan diperoleh pasien dari hubungan yang sifatnya pribadi, misalnya dari pasangan, orang tua, anak, saudara, teman. Perhatian dan kasih sayang adalah bentuk dari dukungan moril yang diberikan dari keluarga.

Maka dari itu peneliti berasumsi sesuai dengan penjelasan di atas bahwa ada pengaruh dukungan keluarga terhadap penurunan nyeri pada pasien fraktur yang sesuai dengan penelitian sebelumnya dan didukung oleh teori.

\section{KESIMPULAN}

Ada pengaruh dukungan keluarga terhadap penurunan nyeri pada psien fraktur di RSUD Salewangan Maros.

\section{SARAN}

Pasien ketika mengalami nyeri sebaiknya keluarga mampu mendapingi dan memberikan suppor agar pasien bias melawan nyeri yang dialaminya. Selain itu pasien juga diharapkan untuk belajar dan mencoba teknik lain untuk mengurangi nyeri, seperti teknik guided imagery dan berbagai terapi lain untuk mengurangi nyeri. 


\section{DAFTAR PUSTAKA}

Andarmoyo, S. 2013. Konsep dan Proses Keperawatan Nyeri. Ar- Ruzz Media Yogyakarta.

Helmi, ZN. 2014. Buku Ajar Gangguan Muskuloskeletal. Salemba Medika : Jakarta.

Lemone, P. 2016. Buku Ajar Keperawatan Medikal Bedah. EGC : Jakarta.

Lukman \& Ningsih,N. 2013. Asuhan Keperawatan pada Klien dengan Gangguan Sistem musculoskeletal. Salemba Medika : Jakarta.

Muttaqin, A. 2012. Buku Saku Gangguan Muskuloskeletal Aplikasi pada Praktik Klinik Keperawatan. EGC : Jakarta

Nurarif, AH \& Kusuma,H.2015. Aplikasi Asuhan Keperawatan Berdasarkan Diagnosa Medis \& NANDA. Jilid II. Mediaction : Yogyakarta.

Notoatmojo. 2012. Metodologi IImu Penelitian Kesehatan. Rineka Cipta : Jakarta.

Nursalam. 2016. Metodologi Penelitian IImu Keperawatan Pendekatan Praktis. Salemba Medika : Jakarta.

Patasik, CR . 2013. Efektifitas teknik Relaksasi Nafas Dalam dan Guided Imagery Terhadap Penurunan Nyeri pada Pasien Post Operasi Sectio Caesare di Irina D BLU RSUP Prof.Dr. R. $D$. KandouManado.Http//ejounal.unsart.ac.id/index.php/jkp/article/viewFile/2169/1727. Di akses 6 November 2016.

Riskesdas,2013.Riset Kesehatan. Dasar Tahun 2013.Http://.www. dinkes. bantenprov. go.id/upload/article_doc/Hasil_Riskesdas_2013.pdf. Di akses 6 November 2016.

Rosdahi, CB \& Kowalski, MT. 2015. Buku Ajar Keperawatan Dasar. EGC : Jakarta.

Rosyidi, K. 2013. Muskuloskeletal. Trans Info Media : Jakarta.

Setiadi. 2013. Konsep dan Praktik Penulisan Riset Keperawatan. Graha IImu : Yogyakarta. 